\title{
Kosovo - særtilfælde eller ny norm
}

\section{Tonny Brems Knudsen}

\section{Hvad kommer det til at betyde, at en lang række vestlige lande nu har anerkendt Kosovo som en selvstændig stat? Vil det åbne for en flodbølge af suverænitetserklæringer, eller vil Kosovo blive an- set for et helt unikt tilfælde?}

I dette nummer sætter Udenrigs fokus på et af de mest sprængfarlige emner i international politik. Nemlig spørgsmålet om ikke uafhængige nationers ret til selvbestemmelse og suverænitet. Spørgsmålet har direkte betydning for fred og konflikt, orden og uorden, inklusion og eksklusion, og det kan derfor ikke undre, at det bestandigt er på det internationale samfunds dagsorden. Dette gælder både, når normerne for nationernes stilling og deres mulighed for selvbestemmelse ligger fast, og det gælder ikke mindst, når disse normer er under forandring eller måske endda opløsning.

En sådan periode med omfattende turbulens og usikkerhed om normerne for national selvbestemmelse, anerkendelse af nye stater og su- verænitetens indhold så vi senest $\mathrm{i}$ forlængelse af den kolde krigs ophør og opløsningen af Sovjetunionen og Jugoslavien i en lang række nye stater. Senest har Kosovos uafhængighedserklæring søndag den 17. februar og den betydelige, men langt fra universelle, internationale anerkendelse heraf igen ført til en omfattende international debat. Ikke bare om selve anerkendelsen af Kosovo, men også om de internationale normer vedrørende nationernes stilling og anerkendelsen af nye stater.

Den aktuelle uenighed om anerkendelsen af Kosovo afspejler i den henseende et velkendt mønster i international politik: Enhver anerkendelse af nye stater, som ikke forekommer at være helt efter bogen, vil 
med stor sandsynlighed føre til en kortere eller længere usikkerhed om de internationale spilleregler på dette punkt. Uenigheden er en understregning af, hvor vigtig spørgsmålet om nye statsdannelser er i international politik. Medlemskab af staternes klub er stadig en eksklusiv ting, og nationale gruppers løsrivelse er en næsten stensikker opskrift på international konflikt.

Debatten om nationernes stilling i det internationale samfund raser således igen. Som et bidrag hertil skal følgende spørgsmål tages op til nærmere overvejelse: 1) Hvilke dilemmaer rejser spørgsmålet om national selvbestemmelse og anerkendelsen af nye stater? 2) Hvilke nationale grupper kan gøre sig håb om suveræn uafhængighed i henhold til international praksis og gældende folkeretlige anerkendelseskriterier,

3) Hvilken præcedens har den aktuelle anerkendelse af Kosovos uafhængighed sat, og med hvilke konsekvenser?

\section{Hvad Folkeretten siger}

Folkeretligt refereres der ofte til Montevideo-konventionen om Staters Rettigheder og Pligter fra 1933, når man skal fastlægge det moderne suverænitetsbegreb. Her fremgår det, at kriterierne for at være en stat i folkeretlig forstand er en permanent befolkning, et defineret territorium og en regering, som i henhold til den dominerende fortolkning også skal have effektiv kontrol inden for dette territorium. Udgangspunktet for det at være en stat er altså et 'effektivitetskriterium', hvoraf også følger at en rigtig stat ikke i udpræget grad kan være under andre staters kontrol.

Ud over denne faktiske evne til at udøve autoritet over en befolkning og et territorium rummer suverænitetsbegrebet imidlertid en række afgørende normative og principielle aspekter: Staten skal være forfatningsmæssig uafhængig, og den skal anerkendes som suveræn af andre stater. Ellers har den ikke alle rettigheder og pligter under international ret, og dermed har den heller ikke fuld adgang til at deltage i den internationale politik på lige fod med andre stater. Sagt på en anden måde er der i henhold til suverænitetens interne aspekt 'ingen ved siden af staten' (effektiv og eksklusiv kontrol over indre anliggender) og i henhold til dens eksterne aspekt 'ingen over staten', hvor det sidste underbygges af normen om gensidig anerkendelse af suverænitet og det formelle lighedsprincip.

I henhold til denne opfattelse, som er funderet i teorien om det internationale systems samfundsmæssige karakter, har suveræniteten altså både en materiel (intern kontrol) og en konstitutiv (ret til deltagelse) dimension, og anerkendelsen af nye stater er både en konstatering af en eksisterende statsevne og en tildeling af en status som stat, der 
ikke kan erhverves på nogen anden måde.

Den moderne legitimering af suveræniteten findes i princippet om national selvbestemmelse, som imidlertid aldrig har fået en realitet, som svarer til princippets navn. Lige siden idéen om ret til national selvbestemmelse blev født, har den altovervejende internationale holdning været, at dette er et uordensprincip, med mindre det fortolkes restriktivt. Alle nationer i verden kan ikke få deres egen stat. For det første fordi der er så mange nationer eller nationale grupper, at statssystemet ville blive sprængt i stumper og stykker, dersom de alle skulle være selvstændige. For det andet fordi mange nationer er vævet ind $\mathrm{i}$ hinanden i en grad, som gør det umuligt at trække grænserne efter nationale tilhørsforhold, uden at dette vil involvere uoverskuelige folkeflytninger. For det tredje fordi løsrivelse og anerkendelse af nye nationsbaserede stater i fraværet af folkeflytninger ofte vil udløse nye konflikter, enten fordi centralregeringen søger at modsætte sig en løsrivelse med magt, eller fordi løsrivelsen skaber nye mindretal, som straks kræver, at princippet om selvbestemmelse også udstrækkes til dem. Jugoslaviens opløsning i begyndelsen af 1990'erne og den aktuelle konflikt vedrørende Serbien, Kosovo og det serbiske mindretal i Kosovo understreger det med al tydelighed.

Selvbestemmelsesretten åbner, hvis den tages bogstaveligt, simpelthen for en Pandoras æske af løsrivelse og konflikt. Den politiske og folkeretlige fortolkning af denne ret var derfor yderst indskrænkende og sprogligt set temmelig ulogisk i det meste af 1900-tallet: Retten til national selvbestemmelse var forbeholdt allerede eksisterende stater og (fra 1960'erne og frem) kolonistater og mandatområder. Med denne fortolkning har der i det meste af den nyere historie været lagt låg på den radikale udfordring til den internationale orden, som er forbundet med en accept af en almindelig ret til national selvbestemmelse.

Denne forsigtige udlægning af retten til national selvbestemmelse var sammen med effektivitetskriteriet (regeringens kontrol over befolkning og territorium) udgangspunktet for anerkendelsen af nye stater ved den kolde krigs ophør. En ny stat skulle i henhold til den fremherskende opfattelse ikke 'bare' have effektiv kontrol over indre anliggender, den skulle også have en ret til national selvbestemmelse. Der var derfor tale om en restriktiv anerkendelsespraksis, som gav nationer uden stat meget ringe muligheder for at blive anerkendt som suveræne, selv i de tilfælde, hvor der måtte være tale om de facto kontrol over et territorium.

\section{Sovjets og Jugoslaviens opløsning}

Med opløsningen af Sovjetunionen 
og Jugoslavien i starten af 1990'erne og den dermed forbundne anerkendelse af i første omgang 20 nye stater (senere fulgte Montenegro og nu altså også Kosovo) blev der imidlertid sat spørgsmålstegn ved den hidtidige fortolkning af selvbestemmelsesretten: Gjaldt denne ret stadigvæk kun for allerede eksisterende stater, kolonistater og mandatområder, eller skulle den nu også omfatte delstater, eller nationer der tidligere i historien havde været uafhængige, eller måske ligefrem ethvert nationalt mindretal, der effektivt og klart kunne fremføre et krav om national selvbestemmelse?

Ikke mindst tendensen til, at kandidaterne søgte at legitimere deres krav med afholdelse af folkeafstemninger udgjorde i den forbindelse en formidabel udfordring til de vestlige lande, for hvordan kunne man i forlængelse af den kolde krigs ophør og lanceringen af en ny verdensorden baseret på frihedsværdier som demokrati, menneskerettigheder og liberal markedsøkonomi afvise det ene udtryk for frihed, som om noget syntes at appellere til befolkningerne overalt i den tidligere østblok, nemlig national selvrealisering?

De vestlige lande var næppe i tvivl om, at en anerkendelse af nye stater efter Sovjetunionen og Jugoslavien kunne udløse en lavine af løsrivelser, uafhængighedserklæringer og anerkendelser, som kunne ryste såvel den europæiske som den inter- nationale orden. Borgerkrig, international konflikt og kaos i normerne for anerkendelse var en reel risiko, og ifølge nogle iagttagere også en realitet, i årene efter den kolde krigs ophør. Derfor søgte især de vestlige lande efter et sæt af kriterier, som kunne muliggøre den i stigende grad uundgåelige anerkendelse af en række efterfølgerstater til Sovjetunionen og Jugoslavien.

En sådan anerkendelsesbølge var grundet opløsningsprocessens egendynamik uundgåelig for Sovjetunionens vedkommende. Hvad Jugoslavien angik, var det indledningsvis Vestens politik, at denne stat skulle forblive en enhed. Men løsrivelseskrigene, Kroatiens og Sloveniens evne til at holde på et territorium samt ikke mindst kampenes brutalitet førte hurtigt til et holdningsskifte i en række centrale stater. Udfordringen var herefter at finde en formel, som kunne muliggøre anerkendelsen af et begrænset antal stater efter Sovjetunionen og Jugoslavien uden at fremprovokere en ukontrollabel bølge af løsrivelsesforsøg eller kaos i kriterierne for anerkendelse.

\section{De nye principper}

Anført af Vesten blev løsningen at fremsætte et princip om, at man kan anerkende delstater eller republikker med interne grænser, når den føderation de er en del af, går i opløsning. Autonome områder, provinser og lignende konstruktioner in- 
den for en republik eller en føderation skulle imidlertid ikke anerkendes efter dette princip, selvom der måtte være 'administrative' grænser at gøre det efter, og nationale gruppers krav skulle slet ikke tages i betragtning. Det særlige ved republikkerne eller delstaterne var ifølge denne argumentation, at disse i forvejen havde klare grænser og en vis statslig status, som gjorde en anerkendelse mulig og kontrollerbar. Dette gjaldt i henhold til denne argumentation ikke for eksempelvis provinser, og da slet ikke for nationale grupper som sådan.

Det bærende princip for anerkendelsesbølgen i starten og midten af 1990'erne var således et (tillempet) effektivitetskriterium, hvor hovedvægten lå på forekomsten af eksisterende grænser, men - til forskel fra tidligere praksis - nu også i form af interne republikgrænser i føderalstater under opløsning. Til gengæld var man især for Kroatiens og Bosniens vedkommende ikke i stand til at opretholde princippet om fuld effektiv eller definitiv kontrol over det pågældende territorium. Dermed kom den konstitutive virkning af anerkendelserne også til at træde klarere frem, eftersom den internationale anerkendelse i nogen grad var med til at skabe Kroatiens og Bosniens suverænitet, ikke blot de jure, men også de facto.

Til gengæld sendte bølgen af anerkendelser i starten af 1990'erne ikke noget signal om, at det interna- tionale samfund nu omsider var parat til at give retten til national selvbestemmelse tilbage til nationerne. En sådan præcedens ville man for enhver pris undgå. Det var republikkerne i de to føderationer, der fik anerkendt deres suverænitet, og grænserne blev ikke trukket efter nationale skillelinjer, men efter de eksisterende politiske grænser.

Den umiddelbare konsekvens af dette princip var, at områder som eksempelvis Abkhasien, Sydossetien, Transdnestr, Tjetjenien og Tatarstan i det tidligere Sovjetunionen, og Kosovo, Vojvodina, Krajina og Srpska i det tidligere Jugoslavien ikke skulle anerkendes som suveræne stater.

Disse områder kunne vel være de facto selvstyrende og uafhængige (som i tilfældet Abkhasien, Sydossetien, Transdnestr og NagornoKarabakh), de kunne kæmpe nok så indæt på basis af et oplevet retfærdigt krav om national selvbestemmelse (som i tilfældet Tjetjenien), og de kunne have nok så klare interne eller administrative grænser som i tilfældet Kosovo og Vojvodina. Men i fravær af tidligere status som republik i en føderation under opløsning skulle de ikke anerkendes.

Baggrunden for denne justering eller reformulering af principperne for anerkendelsen af nye stater var især for Jugoslaviens vedkommende - i høj grad politisk. Det kom bl.a. til udtryk ved de åbenlyse overvejelser om anerkendelse som et konfliktløsningsinstrument, og ved visse sta- 
ters sympati for en anerkendelse af især Kroatien og Slovenien. Men det lykkedes, til trods for disse politiske og pragmatiske overvejelser, alligevel at knytte anerkendelserne til de gældende folkeretlige kriterier, og den præcedens som hermed blev sat, havde en begrænset rækkevidde.

Med muligheden for at anerkende republikker i føderationer under opløsning havde man skabt en tilføjelse til de etablerede kriterier, som nok kunne sende problematiske signaler til løsrivelsesrepublikker i andre føderale statskonstruktioner. Men almindelige krav om national selvbestemmelse kunne man stadig dæmme op for. Europa slap ikke for turbulens, løsrivelsesfors øg, borgerkrige og skuffede forventninger i starten og midten af 1990'erne, men der var ikke tale om kaos, hverken politisk eller folkeretligt.

Lidt senere så semi-statslige, men ikke suveræne konstruktioner som Srpska i Bosnien dagens lys, Montenegro fik selvstændighed efter overenskomst med Serbien (hvilket er efter bogen), og Øst-Timor fik omsider sin uafhængighed fra Indonesien med udgangspunkt i det veletablerede princip om, at kolonistater har ret til selvstændighed efter 'saltvandskriteriet'. Den ret havde $\emptyset_{\text {st- }}$ Timor i forhold til den tidligere kolonimagt Portugal, hvilket en folkeretsstridig indonesisk besættelse ikke kunne lave om på. Efter den umiddelbare turbulens i forbindelse med Sovjetunionens og Jugoslaviens opløsning har der med andre ord været relativ stabilitet og forudsigelighed vedrørende anerkendelsen af nye stater fra midten af 1990'erne og frem. Territorium, grænser og (mere eller mindre) effektiv kontrol var stadig udgangspunktet for anerkendelsen af nye stater - ikke nationen. I hvilket omfang rokker anerkendelsen af Kosovo ved dette?

\section{Folkeretsstridig anerkendelse?}

Kosovos uafhængighedserklæring af 17. februar 2008 og den efterfølgende anerkendelse af Kosovo som et suverænt land anført af Vesten har naturligt nok ført til heftige diskussioner om anerkendelsens folkeretlige gyldighed, dens mulige præcedensvirkning og de politiske konsekvenser.

Som nævnt har anerkendelsen af suverænitet både materielle og konstitutive aspekter, og en overvejende konstitutiv tilgang til anerkendelsesproblematikken åbner - til forskel fra en deklarativ tilgang som tager udgangspunkt i tilstedeværelsen af effektiv kontrol over indre anliggender - i nogen grad for skabelsen af en ny stat som en viljesagt. Men uanset hvordan man vægter de to aspekter, så opererer folkeretten med et begreb om utidig anerkendelse. I sådanne tilfælde er der ikke bare tale om en uvenlig handling over for moderstaten, men også om en folkeretsstridig interventionshandling. Er den internationale anerkendelse af 
Kosovo netop det, sådan som det hævdes af bl.a. Serbien og Rusland? Imod denne påstand taler, at Kosovo har et klart defineret territorium, nemlig de interne provinsgrænser fra tiden i Serbien og Jugoslavien. Kosovo har også en regering med en vis evne til at udøve kontrol over dette territorium. Man kan dog diskutere, om regeringen er uafhængig af det internationale samfund, og om den ville være i stand til at udøve effektiv autoritet inden for hele Kosovo uden den internationale tilstedeværelse, særligt FN, EU og NATO. Omvendt gælder det for en lang række stater i det moderne internationale samfund, at de næppe kan siges at leve op til kriterierne om uafhængig og effektiv autoritet over hele deres territorium, og det folkeretlige krav herom er heller ikke absolut. Statsevnen taler således ikke imod anerkendelsen af Kosovo som uafhængig stat, men den taler heller ikke ubetinget for.

Mere alvorligt kan anerkendelsen af Kosovo siges at hvile på en regulær intervention udefra. Dels fordi Serbien ikke vil acceptere Kosovos uafhængighed, dels fordi Kosovos de facto uafhængighed anno 2008 er en følge af NATOs humanitære intervention i 1999, som ikke var autoriseret af FN's Sikkerhedsråd.

Baggrunden for Kosovos uafhængighed er indiskutabelt et forløb, der begyndte med et kosovoalbansk oprør mod det serbiske styre, en brutal nedkæmpelse af dette oprør rettet også mod civilbefolkningen, og en humanitær intervention, som sigtede på at stoppe disse overgreb. Herefter kom oprettelsen af et de facto $\mathrm{FN}$-protektorat baseret på Sikkerhedsrådets resolution 1244 af 10 . juni 1999, en beslutning som Rusland støttede, men som rest-Jugoslavien inklusive Serbien kun gik med til under pres og ud fra en præmis om, at der ikke var lagt op til fuld suverænitet for Kosovo i denne resolution.

Set i dette lys, som kritikerne af Kosovos nylige uafhængighed hælder til, hviler denne uafhængighed altså i sidste instans på en folkeretligt tvivlsom militær intervention tilbage i 1999. Men formålet med NATOs intervention i 1999 var efter alt at dømme ikke et ønske om at oprette en ny stat. Man ville simpelthen stoppe afbrændingen af kosovoalbanske landsbyer, drabene på civile, som i flere tilfælde antog karakter af massakrer, og den interne og eksterne fordrivelse af store befolkningsgrupper. Denne humanitære intervention var i snæver forstand folkeretsstridig, da den ikke hvilede på et mandat fra FN's Sikkerhedsråd, men den kunne gives et vist folkeretligt forsvar baseret på den humanitære folkeret og FN's egen praksis for humanitær intervention eller slet og ret et princip om humanitær nødvendighed.

Uanset om man hælder til påstanden om ulovlig humanitær intervention eller folkeretligt berettiget hu- 
manitær intervention, så kom protektoratet og Kosovos overgang til reelt selvstyre i stand som en konsekvens af en humanitær intervention, og ikke som et mål i sig selv. Kosovos aktuelle evne til at styre sig selv, og den reelle uafhængighed af Serbien, er i øvrigt en følge af, at FN-administrationen i overensstemmelse med Sikkerhedsrådets resolution 1244 har ført Kosovo frem til dette punkt. Hermed er en anerkendelse efter effektivitets- eller de facto kriteriet, en handling, der kan gives et folkeretligt forsvar.

Sikkerhedsrådets resolution 1244, som ordnede forholdene i Kosovo og oprettede FN-protektoratet efter at serberne havde bøjet sig for NATOs bombekampagne i 1999, var ganske vist ikke udtryk for Sikkerhedsrådets accept af angrebet på Jugoslavien. Det var imidlertid Sikkerhedsrådets bud på en ordning af forholdene i Kosovo. Protektoratet hvilede således i en beslutning fra FN's Sikkerhedsråd, og - kan det argumenteres - dermed i folkeretten. Det største problem med anerkendelsen af Kosovos uafhængighed er dermed, at resolution 1244, som gjorde Kosovo til et protektorat, ikke er afløst af en ny resolution. Hermed kan man sige, at det internationale samfund er endt i temmelig absurd situation, hvor Kosovo for mange stater er en uafhængig stat, mens det for FN som organisation stadig er et protektorat.

FN's generalsekretær Ban Ki-
Moon har sagt i en kommentar til Kosovos uafhængighedserklæring, at anerkendelse ikke er en sag for FN som organisation, det er en sag for medlemsstaterne. Og staterne kan - ligesom FN - næppe siges at være forpligtet til at bringe situationen tilbage til før NATOs humanitære intervention, dvs. en genetablering af Serbiens suverænitet over Kosovo. Især ikke når der uomtvisteligt blev begået meget alvorlige overgreb mod den kosovoalbanske civilbefolkning i 1998-99.

\section{Pragmatiske hensyn}

Ultimativt er de stærkeste argumenter for anerkendelsen af Kosovo således de pragmatiske: Hvordan kunne man - efter mere end otte års uafhængighed af Serbien og de voldsomme overgreb i 1998-99 som kulminerede med en fordrivelse af næsten hele den kosovoalbanske befolkning - forlange af denne befolkning, at den skulle vende tilbage til serbisk overhøjhed? Og hvordan skulle man presse albanerne - 90 procent af Kosovos samlede befolkning - til blot et minimum af accept af en sådan politik? Det var først og fremmest på grund af disse overvejelser, at anbefalingerne fra den uafhængige Kosovokommission, International Crisis Group og senest FN's mægler Martti Ahtisaari alle gik på en form for betinget uafhængighed.

Hermed har man bevæget sig væk fra den folkeretlige argumentation 
og over i den politiske. Men anerkendelsen kan godt have en præcedensskabende og folkeretlig betydning, selvom den hviler på politiske og pragmatiske hensyn.

\section{Hvilken præcedens?}

Det forekommer relevant at overveje i hvert fald tre mulige præcedensskabende virkninger af anerkendelsen af Kosovo. Den første tænkelige præcedens kunne være, at alle nationer i verden, som har et klart flertal inden for et defineret territorium, og som har en væsentlig statsevne, nu kan gøre sig håb om international anerkendelse som suveræn stat. Dette ville bringe en række nationer i spil som umiddelbare kandidater til en snarlig anerkendelse som fuldt suveræne stater, fx kurderne, baskerne, abkhaserne, tjetjenerne, serberne i Srpska, russerne i Transdnestr, og ungarerne i Vojvodina og Rumænien.

Der er næppe tvivl om, at flere af disse nationer uden (rigtige) stater har fået forstærket deres forhåbninger oven på anerkendelsen af Kosovo. Nogle af dem har ligefrem en regering med de facto kontrol over indre anliggender inden for et klart defineret territorium. Men den vestlige og internationale anerkendelse af Kosovo hviler ikke på et argument om, at en nation kan anerkendes, når den har en klart defineret territorium og en regering med effektiv kontrol over indre anliggender. Ar- gumentet er i stedet, at der kan anerkendes, når sådan en nation samtidig har været udsat for forbrydelser mod menneskeheden som defineret i folkeretten (fx Romstatutten for International Criminal Court fra 1998). Dette var, som minimum, tilfældet i Kosovo i 1998 og 1999.

Den anden, og mere sandsynlige, præcedens af anerkendelsen af Kosovo kunne derfor være, at nationer, som er i klart flertal inden for givne grænser, og som har en betydelig grad af de facto kontrol over dette territorium, nu kan gøre sig håb om international anerkendelse, hvis de har været udsat for alvorlige overgreb. Denne mulige præcedens er ikke uproblematisk, for så gælder det 'bare' om at sørge for at få fremprovokeret sådanne alvorlige overgreb under den humanitære folkeret. Meget tyder endda på, at dette faktisk var en del af UCK's (den kosovoalbanske oprørsbevægelses) strategi i forbindelse med oprøret i 1998-99.

Men der knytter sig på den anden side en række ganske særlige politiske omstændigheder til det forløb, der ledte frem til anerkendelsen af Kosovo. For det første den omstændighed, at Serbien og serberne på grund af uhyrlighederne i Bosnien allerede inden overgrebene i Kosovo havde fået et internationalt ry for at overtræde den humanitære folkeret. For det andet at serbiske styrker tidligere havde lidt militære nederlag, som gjorde en betydelig militær 
modstand over for en international intervention usandsynlig. For det tredje, at humanitære interventioner, som den der fandt sted i Kosovo i 1999, hørte til dagens orden i denne periode til forskel fra situationen efter '11. september', hvor sådanne lader til at forekomme sjældnere. For det fjerde, at der faktisk var en kreds af lande, som var parate til at intervenere. Og for det femte, at udgangen på den omstridte humanitære intervention blev oprettelsen af et FN-protektorat, som undlod at fastslå en klar fremtidig status.

Med et (strategisk) oprør, forbrydelser mod menneskeheden begået eller accepteret af centralregeringen i Beograd, en humanitær intervention uden mandat fra FN's Sikkerhedsråd, oprettelsen af et de facto FN-protektorat og sluttelig anerkendelsen af Kosovos uafhængighed er der på den ene side tale om et problematisk forløb, som sender et problematisk signal til andre løsrivelsesnationer, nemlig at oprør nogle gange betaler sig. På den anden side må man give Vesten ret $\mathrm{i}$, at der virkelig har været tale om et helt unikt forløb, som kun kan forventes gentaget i meget få tilfælde. Tjetjenerne har været udsat for forbrydelser mod menneskeheden, men at skabe effektiv kontrol over indre anliggender er en håbløs opgave. Flere af de andre omtalte nationer har denne effektive kontrol over indre anliggender, men de har ikke været udsat for omfattende forbrydelser mod menneskeheden, og de kan næppe heller (risikere at) fremprovokere noget sådant. Kurderne i det nordlige Irak, som allerede har fået en høj grad af national selvbestemmelse, og palæstinenserne kan måske siges at være eksempler med en vis lighed med kosovoalbanerne. Nogle vil hævde, at det samme gælder for serberne i Krajina. Men der er ikke åbnet for en bølge af nye anerkendelser, og der er heller ikke nogen åben invitation til nationale grupper om at forsøge sig med et oprør.

Det sidste er dog langt fra alene en konsekvens af en ideel international retsorden, men nok så meget af de magtpolitiske forhold. De etablerede stater har vedvarende fat $\mathrm{i}$ den lange ende, og de ønsker som udgangspunkt ikke at øge antallet af suveræne medlemmer af det internationale samfund.

Der kan som en tredje overvejelse imidlertid argumenteres for, at der med anerkendelsen af Kosovo er sat en - i henhold til folkerettens beskyttelse af menneskerettighederne og de nationale mindretal - mere positiv præcedens vedrørende 'betinget suverænitet'. Suveræniteten er ikke længere absolut. Folkemord og forbrydelser mod menneskeheden kan i dag føre til såvel en midlertidig (humanitær intervention og protektoratstyre) som en permanent fortabelse af suverænitet (anerkendelse af nationale mindretal, som har været udsat for overgreb).

Samtidig er der i tilfældet Kosovo 
knyttet en række betingelser til suveræniteten, som næppe har noget historisk fortilfælde. Den plan for Kosovos betingede suverænitet, som FN's mægler Marrti Ahtisaari har lagt frem er ganske vist ikke blevet konfirmeret i FN's Sikkerhedsråd grundet primært den russiske modstand mod Kosovos uafhængighed. Men det er den plan, som den internationale anerkendelse og Vestens fortsatte støtte hviler på, og det er også den plan, som Kosovos regering og parlament foreløbig har holdt sig til i form af vedtagelsen af en række nye love.

Til betingelserne for Kosovos uafhængighed hører bl.a. beskyttelse af serbiske lokalsamfund, mulighed for lokal selvbestemmelse og beskyttelse af den serbisk-ortodokse kirke og kultur. Samtidig er det forudset, at dette skal sikres gennem en fortsat international militær og civil tilstedeværelse i Kosovo, og en institutionaliseret overvågning af, at Kosovos regering faktisk lever op til disse betingelser; en opgave der på ubestemt tid er lagt i hænderne på en international civil repræsentant. Denne opgave vil i praksis være op til EU og måske også FN-missionen (UNMIK).

Det kan igen indvendes, at Kosovo er en helt unik case, og at Vestens engagement og prestigemæssige overvejelser er en afgørende forudsætning for, at der i dette tilfælde stilles reelle betingelser til suveræniteten. Moralsk og principielt kan hverken Vesten eller FN (hvis generalsekretær har anbefalet betingelserne for Kosovos uafhængighed) holde til, at et selvstændigt Kosovo udsætter det serbiske mindretal for noget, der ligner den behandling, som kosovoalbanerne blev ofre for i 1998-99. Noget der ikke har forekommet helt usandsynligt set i lyset af martsurolighederne i 2004, hvor det serbiske mindretal i Kosovo blev udsat for en række overgreb. De opstillede betingelser for anerkendelsen af Kosovo stemmer imidlertid meget godt overens med FN's og Vestens humanitært funderede tilgang til konflikterne i dette land siden 1990'ernes slutning, og den internationale tendens til at kræve garantier for nationale og andre mindretal siden den kolde krigs ophør antyder ligeledes, at den absolutte suverænitets dage er ovre.

\section{Efter anerkendelsen}

På trods af denne mere positive fremstilling af anerkendelsen af Kosovo, er det ikke nogen køn situation, som denne nye stat, Europa og FN er havnet i. Kosovo må i dag siges at være en (slags) suveræn stat, men en række stater med Rusland, Kina og Serbien i spidsen vil i hvert fald foreløbig ikke regne Kosovo som sådan. Kosovo kan heller ikke umiddelbart blive medlem af FN, der efterhånden er blevet selve symbolet på fuld deltagelse i det internationale samfund. Der er derfor 
ikke tale om fuld deltagelse i det internationale samfund, og Kosovo kan næppe heller oppebære samtlige rettigheder og pligter under international ret. Endvidere er der stadig en oplagt risiko for en de facto opdeling af Kosovo i en albansk og en serbisk del.

For FN er problemet at Kosovo i henhold til Sikkerhedsrådets resolution 1244 fra 1999 fortsat er under FN-administration. UNMIK må derfor foreløbigt fortsætte, sådan som FN's generalsekretær også har lagt op til. Den planlagte overdragelse af det statsbyggende og kontrollerende ansvar til EU kan kun ske inden for rammerne af resolution $1244 \mathrm{og}$, formentlig, under forudsætning af en form for fortsat FN-administration.

Groft sagt må Kosovo derfor indtil videre rent formelt og formentlig også reelt forblive en slags protektorat for FN (som fastlagt i resolution 1244), mens Kosovo for EU vil være en selvstændig stat, som organisationen samtidig må understøtte og overvåge. Dette sætter såvel EU som FN i en mærkværdig situation, uanset om man placerer hovedansvaret for denne situation i Beograd, Moskva eller de vestlige hovedstæder.

Endelig kan det anføres, at den europæiske familie af stater nu for alvor fremstår som en broget og uhomogen forsamling. Billedet af det stringent organiserede statssamfund, hvor al autoritet ligger hos fuldt suveræne og fuldt effektive sta- ter og ingen andre steder, er for længst krakeleret. I stedet har vi et internationalt politisk spil præget af tilstedeværelsen af mange forskellige aktører, overlappende suverænitet (EU), betinget suverænitet (Kosovo og til dels Bosnien), de facto, men ikke de jure, selvstyrende stater (fx Transdnestr og Abkhasien), semi-selvstændige enheder (fx Srpska) og en kompleks dynamik af typen inklusion/eksklusion (vedrørende medlemskab af det internationale samfund eller EU).

Politisk set er dette en stor udfordring, akademisk set er det bare spændende. Men for nationer uden stater er billedet overvejende uændret: De skal - realistisk bedømt fortsat ikke gøre sig de store forhåbninger.

\section{Tonny Brems Knudsen er lektor ph.d $i$} international politik på Institut for Statskundskab ved Aarhus Universitet.

\section{Udvalgt litteratur:}

Christensen, Per Bredholt (2002), Anerkendelse af Stater, København: Jurist- og Økonomforbundets Forlag.

Crawford, James (1979), The Creation of States in International Law, Oxford: Clarendon Press.

Knudsen, Tonny Brems \& Carsten Bagge Laustsen (2006) (eds.), Kosovo between War and Peace: Nationalism, Peacebuilding and International Trusteeship, London: Routledge.

SNU (1994), Magt og normer $i$ international politik, København: SNU.

UN Security Council, S/2007/168/Add.1, "Comprehensive Proposal for the Kosovo Status Settlement". 